\title{
"Eis Quem Surge no Estádio: É Atalante!" A História das Mulheres nos Jogos Gregos
}

Paula Viviane Chiés*

\begin{abstract}
Resumo: O estudo buscou indícios da participação feminina em Jogos Gregos, entre eles, os Jogos Olímpicos. Analisando a participação das mulheres nesses eventos, o texto discute as justificativas que determinavam a proibição, ou mesmo, a limitação desse grupo em fazer parte de atividades do mundo masculino na civilização grega. Para contextualizar essas justificativas, o estudo também ressalta as principais características de cada fase educacional grega, diferenciando a educação realizada em Esparta, na qual as mulheres possuíam um espaço maior para a prática de atividades esportivas e em Atenas, na qual a educação feminina restringia-se ao caráter doméstico, não havendo a preocupação com o preparo físico das mães para desempenharem os seus afazeres do lar, ou mesmo, para gerarem filhos robustos e sadios.

Palavras-Chaves: História. Jogos gregos. Mulheres.
\end{abstract}

\section{INTRODUÇÃO}

Dentro da cronologia oficial de Olímpia e de seus Jogos é consagrada a primeira Olimpíada em 776 a.C, na qual a corrida, única prova disputada foi ganha por Corebos de Elida. Essa cronologia percorreu até a data de 408 d.C, momento no qual através dos decretos de Teodósio II, então imperador do Oriente, os Jogos Olímpicos foram abolidos, assim como qualquer outro tipo de cerimônia considerada pagã. O Templo de Zeus em Olímpia, então, marco dos rituais e exaltação dos deuses em todas as provas dos Jogos, foi destruído como conseqüência da aplicação dos decretos imperiais (DURANTEZ, 1975).

\footnotetext{
* Mestre em Pedagogia do Movimento Humano pela EEFE da USP. Participante do Centro de Estudos Socioculturais do Movimento Humano e G.E. em História e Antropologia do
} Movimento Humano. E-mail: paulachi@usp.br, paulachies@hotmail.com

Movimento, Porto Alegre, v.12, n. 03, p. 99-121, setembro/dezembro de 2006. 
Os Jogos Olímpicos permanecem inertes por muitos séculos, dormentes junto aos destroços daquelas que foram as suas principais construções e símbolos de louvor. Somente no século XIX, dinamizada pela figura de Pierre de Frédy, barão de Coubertin (1863-1937)1, é celebrada em 1896 a primeira Olimpíada da época moderna. Como havia de ser pela lógica histórica, ela foi realizada em Atenas, e contou com a participação de 13 nações e 484 participantes.

Pierre de Coubertin foi uma figura marcante no pensamento moderno, tendo associada a sua imagem a elucidação do valor histórico e da importância em reunir os diferentes povos em prol do que circundava o ideal olímpico. Essa imagem refletiu-se em sua defesa da paz durante o caótico período vigente da II Guerra Mundial (1914-18), no qual para ele apenas a paz romperia a incompreensão, a barbárie e a incultura, elementos impulsionadores dos conflitos bélicos (DURANTEZ, 1975).

No entanto, perante o conjunto de suas idéias mais difundidas, principalmente, àquelas que identificamos como propulsoras da reflexão contra a inutilidade da guerra e de renascimento da história do esporte universal, Coubertin não apenas não concebia a possibilidade das mulheres participarem dos Jogos, como também era fielmente contrário a essa inovação. Para ele as mulheres deveriam restringir-se a cuidar dos filhos, enquanto as competições desportivas seriam um atrativo aos homens. Uma Olimpíada com a presença feminina não seria prática, nem interessante, nem estética e nem correta, essas eram as palavras de Coubertin quando indagado acerca da hipótese de inclusão das mulheres nos Jogos (FAURIA, 1973).

Coubertin buscava reproduzir, impecavelmente, a estrutura da sociedade antiga, os valores e costumes que formaram a civili-

${ }^{1}$ Nasceu em Paris em 1 de janeiro de 1863, pertencente a uma tradicional família da nobreza francesa. Faleceu em 1 de setembro de 1937, então com 74 anos de idade (DURANTEZ, 1975, p.352).

Movimento, Porto Alegre, v.12, n. 03, p. 99-121, setembro/dezembro de 2006. 
zação grega. Nesse sentido, por tradição a polis era um "clube de homens", um sistema de vida em sociedade que enaltecia os valores masculinos e jogava nas sombras as mulheres, mães, esposas e filhas (SCHNAPP, 1996). Às mulheres era proibida a participação em assuntos como a política, a economia, e nos jogos gregos a imagem feminina só poderia ser citada pela visão da sacerdotisa que trazia boa sorte ao competidor ou como aquela que o consagrava pela vitória com a coroa do triunfo. Como exemplos dessa perspectiva, encontramos em diversas figuras da Grécia Antiga, imagens reportando-se a Niké, a deusa da vitória.

Refletindo acerca desse contexto como podemos discutir a participação feminina ativa, como atleta e competidora nos "Jogos Olímpicos" ou em outras competições atléticas na Grécia Antiga? A história nem sempre é apenas aquela que nos contam, há uma história esquecida ou menosprezada frente aos outros fatos.

\section{A MULHER NA EDUCAÇÃO GREGA: AS DIFERENÇAS ENTRE ESPARTA E ATENAS}

Diferente de qualquer outro povo antigo, os espartanos davam às mulheres praticamente o mesmo tipo de educação que aos homens, mas sem nenhum outro fim mais elevado que o de preparar mães de guerreiros. O objetivo da educação espartana era oferecer a cada indivíduo tamanha perfeição física, coragem e hábito de obediência completa às leis, que os modelassem como o soldado ideal, insuperável em bravura. Um soldado no qual o indivíduo estivesse submetido ao cidadão. O homem espartano representava o vigor, a tenacidade e o domínio de si mesmo, o que muitas vezes faltava aos outros gregos. A mulher espartana representava a dignidade, a capacidade para enfrentar as vicissitudes da vida, a habilidade para aproveitar oportunidades que, a não ser no período primitivo, foram negadas às mulheres de outra parte da Grécia (MONROE, 1972).

$\mathrm{Na}$ educação ateniense também havia essa supremacia aos

Movimento, Porto Alegre, v.12, n. 03, p. 99-121, setembro/dezembro de 2006. 
interesses do Estado em relação ao indivíduo, no entanto, isso ocorria diferentemente da educação espartana. Na educação ateniense, um cidadão que dirigia a sua vida pela razão e que fosse atento ao cumprimento de seus deveres públicos exigidos pelo Estado, ainda mais, livre nas suas horas de folga e na interpretação das obrigações sociais - não poderia ser formado por uma educação inteiramente dominada por um despótico regime socialista como em Esparta.

A educação ateniense compreendia a educação intelectual ou musical e a educação física ou ginástica, diferenciava-se ainda de acordo com a idade dos educandos, dividindo-se em dois ciclos: a educação da infância que chegava até os quinze anos de idade e a educação da juventude ou dos efebos que se prolongava até os vinte anos (SANTOS, 1958).

$\mathrm{Na}$ educação da infância, depois de um intenso treino até os sete anos de idade, em que o menino ficava sob os cuidados da mãe, ele era tirado do lar e colocado sob os cuidados dos auxiliares - o "pedônomo" e o "irene", instrutores públicos, que eram rapazes mais velhos que os demais (GRIFI, 1989). Por volta dos treze anos, completava-se a educação elementar. As crianças mais pobres eram orientadas na busca de um ofício, e as de família rica continuavam os seus estudos, sendo encaminhadas a um ginásio. A palavra "ginásio" inicialmente significou o local para a cultura física onde, com freqüência, os gregos apresentavam-se despidos, daí originando-se de gimnos, "nu". Com o tempo as atividades musicais se ampliaram em discussões literárias, adotando-se o estudo da matemática, geometria e astronomia. Depois da criação de bibliotecas e salas de estudo, o ginásio adquiriu caráter mais próximo do conceito moderno de local de educação secundária (ARANHA, 1989).

Quando os jovens completavam dezoito anos, eram identificados como efebos. Dessa forma, tornavam-se maiores de idade e aptos para o serviço ativo do Estado, que durava dois anos. De-

Movimento, Porto Alegre, v.12, n. 03, p. 99-121, setembro/dezembro de 2006. 
pois desse período prestavam, então, o juramento dos efebos em um templo de Atenas ao pé da Acrópole, uma cerimônia de caráter militar e cívico. A partir dessa cerimônia, os jovens entravam em outra fase de formação, na qual recebiam uma preparação militar nos acampamentos do exército.

Na educação espartana, ao sete anos, o menino também era retirado do ambiente familiar, momento no qual o Estado praticamente apossava-se da criança, oferecendo-lhe uma educação pública e obrigatória. A criança passava a viver em comunidade, em grupos divididos conforme a idade e supervisionados pelos rapazes mais velhos. Até aos doze anos predominavam as atividades lúdicas, entre eles a música, o canto e a dança coletiva. Conforme a criança crescia, aumentava o rigor da aprendizagem e a "educação física" se transformava em verdadeiro treino militar (ARANHA, 1989).

A educação espartana desenvolvia uma ampla gama de jogos gímnicos e, ao mesmo tempo, deviam manter e observar a mais severa disciplina; deviam mostrar-se indiferentes ao frio, à fome, à sede e a todo tipo de fadiga. A prática de exercícios físicos tinha uma importância extraordinária, tanto que a história indica como sendo os espartanos os primeiros vencedores de muitos jogos competitivos e também como inventores de alguns deles como, por exemplo, o pugilato e o pancrácio (competição que compreendia a luta e o pugilato) (GRIFI, 1989).

A ginástica para os espartanos era um meio para fortificar-se o corpo, preparando-o para a guerra, a defesa da polis. O caráter agonístico nas atividades educacionais espartanas fez com que fossem responsáveis pela origem da ginástica militar, na verdadeira acepção da palavra, pois a sua ideologia estava voltada para essa filosofia. Junto à ginástica e aos exercícios militares, praticava-se em lugar secundário a dança e a música.

Do ponto de vista cultural-intelectual, os jovens aprendiam a ler e a escrever o estritamente necessário às exigências da vida.

Movimento, Porto Alegre, v.12, n. 03, p. 99-121, setembro/dezembro de 2006. 
Também em Esparta originou-se a extensão dos exercícios físicos às mulheres que eram virilmente voltados à preparação do corpo para torná-las mães fortes e robustas.

As mulheres espartanas tomavam parte em todos os exercícios e trabalhos, praticavam todas as atividades masculinas, inclusive a luta e o pugilato. Os exercícios procuravam desenvolver na mulher a força física, sendo adestradas desde cedo na realização de trabalhos domésticos, muitas vezes, em afazeres que exigiam esse preparo físico: transportar água, moer grãos, etc. (RAMOS, 1982).

A educação feminina em Esparta também era função do Estado, o dever das mulheres era, antes de tudo, trazer à pátria filhos sadios e vigorosos. Elas praticavam em campos especiais, divididas em classes, conforme a idade, o salto, a corrida, a luta, o lançamento de disco e de dardo, o canto e a dança. Essas mulheres trajavam apenas uma leve túnica de lã, do mesmo modo que os rapazes. Os costumes espartanos permitiam relações mais próximas e livres entre os sexos, tanto que em certas festas religiosas, havia danças e cânticos em que os rapazes e as raparigas participavam inteiramente desnudos (SANTOS, 1958).

Por outro lado, na educação ateniense, as meninas passavam por uma formação inteiramente doméstica. As mães ensinavam às suas filhas todas as tarefas do lar, transmitiam ainda certas noções de higiene física e preceitos morais, mas a educação intelectual era nula. Elas eram preparadas exclusivamente para a vida familiar, somente as hetairas, escravas dançarinas ou tocadoras de flauta, recebiam alguma instrução intelectual.

\section{GINÁSIOS, PALESTRAS E HIPÓDROMOS: LOCAIS DE TREINAMENTO E AS PROVAS DESPORTIVAS}

Nos primórdios da civilização grega, todos os exercícios eram realizados ao ar livre, em locais sem nenhuma preparação especial, mas geralmente planos, revestidos de vegetação, som- 
breados e próximos de água. Com o tempo surgiram instalações apropriadas aos treinamentos e competições: o ginásio, a palestra, o estádio e o hipódromo, todos constituíam os principais locais de prática (RAMOS, 1982).

O ginásio, entre os gregos, era a escola pública na qual se ensinava a ginástica para a juventude, otimizando a sua saúde, desenvolvendo e conservando a robustez física do organismo. $\mathrm{O}$ ginásio grego não se dedicou apenas aos exercícios atléticos, também passou a orientar a cultura física geral da criança. Conjunto ao estudo das letras e da música, o ensino trabalhado nos ginásios compreendia a educação da mocidade. Todo o grego que aspirasse a estima de seus concidadãos deveria freqüentar o ginásio pelo período de 10 anos até a maioridade, para que obtivesse o diploma que lhe permitiria o ingresso em cargos públicos (BOGA, 1964).

Os principais ginásios gregos eram os das cidades: Atenas, Olímpia, Epidauro, Delfos, Pérgamo, Messênia, Delos e Éfeso. Em Atenas existiam três estádios: a Academia, o Liceu e o Quinosargo, todos localizados dentro de bosques de oliveiras consagrados às divindades (RAMOS, 1982).

Os ginásios e as palestras constituíam os edifícios mais importantes de qualquer comunidade grega, tanto que as cidades desprovidas de ginásio, eram consideradas bárbaras. A palestra normalmente era uma instituição privada na qual se desenvolvia a prática de exercícios de maneira geral, como a luta, o pugilato e o pancrácio. Algumas instalações apresentavam pistas cobertas (xistos) e recintos adequados para os jogos de bola ${ }^{2}$.

Também na Grécia havia esplêndidos estádios. Em Olímpia, o seu Estádio foi criado em torno de uma lenda, acreditava-se que Hércules havia demarcado o espaço reservado ao estádio, mar${ }^{2}$ Os gregos conheciam, desde os tempos heróicos, jogos simples de bola. Homero des-
creve-nos uma prática semelhante ao handebol. Existem gravuras de atletas jogando uma espécie de golfe, outras mostram-nos algo parecido com o hóquei. (RAMOS, 1982)

Movimento, Porto Alegre, v.12, n. 03, p. 99-121, setembro/dezembro de 2006. 
cando com o pé 600 vezes, colocando-o um a frente do outro. Esse estádio localizado em um vale, media $184,98 \mathrm{~m}$ e consistia em uma pista estreita que terminava em semicírculo. Uma linha reta determinava o ponto de partida para terminar no lado oposto por uma reta paralela para além da qual se levantava um talude para a disputa do pugilato e do pancrácio. A pista compreendia o espaço entre as duas linhas paralelas.

Os estádios, no início, serviam apenas para a corrida de velocidade denominada de "estádio", que correspondia a um percurso em linha reta de $192,27 \mathrm{~m}$. No Estádio de Olímpia eram marcadas as competições olímpicas da Grécia Antiga. Competições como o pugilato, a corrida de cavalos, o atletismo, e muitas outras atividades que tinham importância na formação do cidadão. As provas olímpicas da época clássica apresentavam uma caracterização particular e assumiam uma diferenciação de status social.

Nos tempos heróicos ${ }^{3}$ desconhecia-se a equitação. A corrida de cavalos criada pelos antigos persas nas festas dedicadas ao deus Sol (Mithra), foi introduzida na Grécia por Hércules. Os gregos não conheciam a sela, os estribos, nem o freio, como demonstra um dos baixos relevos do friso do Parthenon, representando a procissão das Panatheneas (BOGA, 1964).

Com o passar do tempo, a equitação tornou-se de extremo valor para a nobreza ateniense, sendo delimitada como uma disciplina indispensável que deveria fazer parte de todo boa educação de um jovem. Dessa forma, entre as classes mais altas, o hipismo adquiriu maior predileção, contrário à luta, ao pentatlon, e demais provas que não necessitassem de meios especiais (cavalos, carros) que foram, progressivamente, relegadas a camadas sociais mais amplas, devido a maior acessibilidade (SCHNAPP, 1996).

${ }^{3}$ Os tempos heróicos ou homéricos, vão do século XII ao VII a.C. e são assim chamados porque nesse período teria vivido Homero, autor das epopéias llíada e Odisséia (ARANHA, 1989.

Movimento, Porto Alegre, v.12, n. 03, p. 99-121, setembro/dezembro de 2006. 
$\mathrm{Na}$ escola de equitação realizavam-se provas de doma, exercícios de volteio, arremesso de dardo do cavalo, tiro com arco, salto de obstáculos, combates simulados e o célebre torneio de Tróia, adotado mais tarde em Roma. Nessa escola, a corrida de cavalo, a corrida de carro e os jogos eqüestres eram as três principais modalidades de prática do desporto hípico. Na corrida de cavalos, as distâncias das corridas variavam. O cavaleiro montava geralmente nu e sem sela, e as provas eram programas de acordo com sua idade. Na corrida de carros, o carro era uma caixa baixa sobre duas rodas, muito leve e frágil, puxada por cavalos. Se fossem dois cavalos era chamada biga, três cavalos, triga ou quatro cavalos, quadriga. Essa prova apresentava um caráter aristocrático, tendo sido um dos motivos do surgimento do atleta profissional, cuja atuação beneficiava o proprietário do carro, a quem cabiam os louros da vitória (RAMOS, 1982).

Plutarco (50-124 d.C), cronista da vida grega, classificava o pentatlon como o exercício mais artístico de todos. Essa prova olímpica compreendia, como a própria denominação evidencia, cinco atividades: a corrida a pé, o lançamento do disco e do dardo, a luta corpo a corpo e o salto em distância. A corrida era a mais natural, antiga e popular atividade praticada na Grécia. O "estádio" correspondia à corrida de velocidade $(192,27 \mathrm{~m})$; o "diaulo" ou "duplo estádio", a algo parecido com uma corrida de velocidade prolongada; a "hípica", era análoga a uma das provas de corrida de cavalos, tendo uma extensão de 740m; o "dólico", corrida de resistência, representava um esforço correspondente a 12 ou 24 "estádios".

Em relação ao lançamento, outra prova do pentatlon, acredita-se que os primeiros discos tenham sido de pedra, sem forma determinada até que se aperfeiçoaram tornando-se circulares. Tanto que no leito do rio Alfeu foi encontrado um medindo 7,5 polegadas de diâmetro, cinco vezes mais espesso no centro do que na circunferência, tendo em uma das faces a palavra solos, nome pelo qual primitivamente se designava o instrumento (BOGA, 1964).

Movimento, Porto Alegre, v.12, n. 03, p. 99-121, setembro/dezembro de 2006. 
O pentatlon disputava-se em um dia, ou muitas vezes, em uma manhã. Entre os atletas, os quatro melhores classificados no salto e no dardo eram selecionados para participarem das lutas finais. Os três melhores concorrentes disputavam o lançamento do disco. A partir daí, os dois finalistas classificados nas quatro provas do pentatlon começavam a luta corpo a corpo para decidir o vencedor que recebia a coroa (RAMOS, 1982).

O salto em distância era o único tipo de prova que envolvia a habilidade de "saltar". A partir da XIII Olimpíada, o salto em distância passou a ser praticado com halteres, de pedra ou de chumbo, de várias formas e de um a três quilos. Acreditava-se que seu emprego aumentava a extensão do salto.

O pugilato era outro tipo de luta realizada pelos gregos. Uma luta com os punhos, sendo os atletas armados de "cestos" presos da mão até o antebraço. Esses instrumentos causavam efeitos traumáticos, pois, sob o invólucro comum de couro sobrepunham tiras de couro seco e endurecido, reforçadas com cravos de ferro ou pedaços de chumbo.

Outra atividade considerada essencial na educação grega era a natação, tanto que quem não sabia nadar e escrever era considerado inculto. Os estilos atuais de natação faziam parte do treinamento. Também praticavam o salto, o mergulho e exercícios similares.

\section{DESPERTANDO OS DEUSES: A HISTÓRIA DE MULHERES VENCEDORAS NOS JOGOS GREGOS}

Temos indícios de algumas mulheres que alçaram a vitória em provas pertencentes a Jogos Gregos. A primeira mulher do Olimpismo antigo que conseguiu triunfos foi Kyniska, filha do rei Archidamus II, meia-irmã do rei Agis II (427-400 a.C.) e irmã do rei Agesilaus (400-360 a.C.) (KYLE, 2003).

Os cavalos da princesa espartana, famosa em seu tempo em toda Hélade, venceram a prova de quadrigas (carros puxados por quatro cavalos) da 96 e 97 Olimpíada (396 e 392 a.C.). Com 
tamanho triunfo, à campeã foi dedicada uma quadriga em bronze de tamanho inferior ao natural, colocada no Templo de Zeus em Olímpia (DURANTEZ, 1975).

Kyniska alcançou um alto patamar de honra nos Jogos, tanto que a ela foi dedicado também um epigrama de vitória em Olímpia. Nesse epigrama, encontrado na famosa cidade de Olímpia, essa atleta deixava a todos algumas palavras para a posteridade: "reis de Esparta foram meus pais e irmãos, e eu, kyniska, vencendo a corrida de bigas, recebi esta estátua. Eu afirmo que sou a única mulher em toda a Grécia que ganhei esta coroa".

Muitos estudiosos da história da participação feminina no esporte não acreditam que a vitória de Kyniska nos Jogos represente alguma evolução nesse aspecto. Na verdade sugere-se que a sua participação foi impulsionada por seu irmão Agesilaus, por motivos estritamente políticos, havendo ainda, a supremacia dos interesses dos homens nesses eventos. Agesilaus buscava comprovar através do sucesso de sua irmã que a prova de corrida de cavalos podia ser vencida apenas por uma questão de saúde e não, prioritariamente, pela excelência das características masculinas (KYLE, 2003).

Também nas provas de corrida com cavalos, especificamente, no concurso de quadrigas, destacou-se Belistiche da Macedônia, vencedora na prova de quadrigas de potros da $128^{\circ}$. Olimpíada (268 a.C.) e na de biga de potros da $129^{\circ}$. Olimpíada, modalidade eqüestre introduzida então pela primeira vez ${ }^{4}$ nos Jogos. Esta atleta era a favorita do imperador egípcio Tolomeo Filadelfo, tanto que como mérito aos seus êxitos obtidos, ele dedicou-lhe um templo e um culto, para a sua consagração como a deusa Afrodite Belistiche.

${ }^{4}$ No princípio, nos concursos hípicos, utilizavam-se somente cavalos adultos. Posteriormente, foi adotada uma série de novas modalidades com potros e mulas. (DURANTEZ, 1975).

Movimento, Porto Alegre, v.12, n. 03, p. 99-121, setembro/dezembro de 2006. 
A mulher caçadora na Grécia também é descrita, principalmente, na figura de Atalante, a atleta que ameaçava o mundo masculino nos três domínios peculiares a esse grupo: a caça, a luta e a corrida. Assim como as Amazonas, Atalante questiona o poderio masculino na guerra, e desafia Peleu (pupilo de Quíron) à luta.

Como prova iconográfica da exaltação das intrépidas mulheres nas competições atléticas, os pintores de figuras vermelhas representavam Atalante pronta para a corrida, compondo-se de atributos do atletismo masculino: marca de chegada no estádio, esponja, estrígil:

[...] que o rapaz malogrado, a mulher selvagem das tradições mais antigas, apareça sob os traços elegantes da atleta que expõe seu corpo - equipado com calção, sutiã e capacetena pista do estádio é algo que não poderia exprimir melhor o intenso trabalho dos artistas empenhados em instalar imagens do passado no cenário da cidade do século V. (SCHNAPP, $1996, p .54)$.

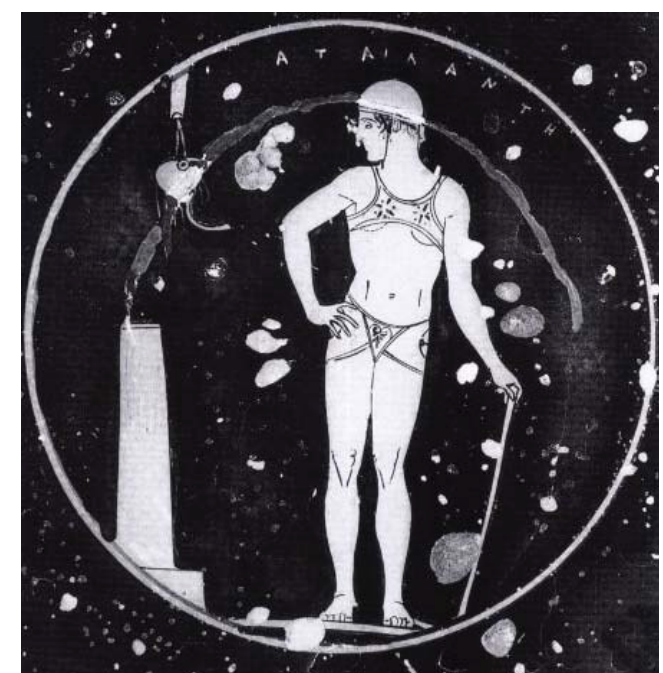

Figura 1 - Atalante - o rapaz malogrado, preparada para uma prova de atletismo. Taça,

Movimento, Porto Alegre, v.12, n. 03, p. 99-121, setembro/dezembro de 2006. 
Essa representação de Atalante pronta para participar de uma competição é algo raro perante os indícios deixados pelos gregos em relação à história dessas jovens, como salienta BÉRARD apud SCHNAPP (1996), a ginástica feminina era representada como uma atividade passiva, nas figuras, elas se lavam e se preparam para o exercício, no entanto, não as vemos na realização do esforço, não por elas não serem capazes de praticá-lo, mas porque seus exercícios não eram considerados dignos de representação.

Artemisa também é um exemplo da glória feminina nos jogos gregos. Como habilidosa caçadora, a fama desta heroína esportiva esteve esculpida e estampada em muitos vasos da Antigüidade, figuras nas quais ela aparece segurando o seu arco e, muitas vezes, junto a seus cães de caça.

Artemisa e Atalante são os símbolos divinos do poder matriarcal, da fertilidade. Junto a elas surgiram Hera, Hipodamia e Penélope. Hera era também símbolo da fertilidade, uma imagem de poder sobre os homens, porém Penélope e Hipodamia eram consideradas férteis prêmios humanos que se entregavam ao vencedor como recompensa de seu triunfo. Entre os cretenses, as mulheres integraram-se às possibilidades lúdicas e agonísticas de seu tempo, desenvolvendo vários exercícios físicos acompanhadas, às vezes, por um homem. Essa liberdade também ocorria nos estádios, podendo assistir aos espetáculos e circular livremente estando ou não em companhia de seu marido. (DURANTEZ, 1975).

Além de dançarem, atividade física típica da educação feminina, elas praticavam o hipismo, o pugilato e a tauromaquia. Assim, formadas as novas comunidades helênicas, insulares, peninsulares e continentais, as mulheres seguem exercitando-se e, ocasionalmente, utilizando-se de seus direitos de participação em competições públicas organizadas.

A comunidade espartana aparece como expoente dessa maior liberdade em relação às mulheres no que dizia respeito à prática de exercícios físicos, sendo as jovens de Esparta adestradas e

Movimento, Porto Alegre, v.12, n. 03, p. 99-121, setembro/dezembro de 2006. 
treinadas, na maioria das vezes junto aos homens, fator que provocava chacotas das mulheres atenienses. Mas isso não impedia a continuação das atividades, pois as leis rigorosas de Licurgo (líder espartano), prescreviam às mulheres do país, não apenas a prática da corrida, ou de alguns jogos com bolas e aros, mas para ele deveriam treinar o lançamento de disco, a luta e o pugilato. Licurgo acreditava que a prática dessas atividades as levaria à capacitação, às condições de cuidarem dos assuntos da família quando da ausência dos maridos em casos de batalha, ou mesmo, otimizariam as descendências, através da formação de corpos preparados e fortes para a fertilidade, para serem mães.

Em Olímpia, foram promovidas competições oficiais somente para as mulheres, esses concursos foram denominados de "Jogos Heranos", nome derivado do culto à deusa Hera. Essa deusa foi venerada como protetora das esposas e mães, e a ela foi construído um tempo (o maior encontrado) em V a.C, localizado entre Argos e Micenas e abrigava a célebre estátua de ouro e marfim de Hera. A deusa representava a bela mulher, jovem e casta, trajando uma longa túnica e um véu, com a cabeça adornada por um diadema e trazendo na mão um cetro. O pássaro consagrado à deusa era o pavão, os gregos associavam a plumagem brilhante e enfeitada da ave à magnificência de um céu estrelado, também reino de Hera (GODOY, 1996).

Esses jogos em louvor a Hera consistiam de corridas a pé, sendo diferenciadas as provas pela idade das jovens. As mais velhas eram as primeiras a correrem e assim por diante. Elas corriam de cabelos soltos, com uma túnica colocada um pouco acima de suas cinturas e o ombro direito nu até a altura do peito. O estádio Olímpico também era reservado a elas para as provas e essas jovens disputavam apenas uma corrida de 162 metros na cidade de Elis. Para as vencedoras entregavam-se as coroas de oliveiras e uma parte da carne da vaca sacrificada a Hera, ou mesmo, ganhavam estátuas com seus nomes inscritos (DURANTEZ, 1975).

Movimento, Porto Alegre, v.12, n. 03, p. 99-121, setembro/dezembro de 2006. 
Embora fosse realizada apenas uma corrida nos "Jogos Heranos", em algumas regiões da Grécia, as mulheres faziam parte de outros eventos esportivos. Inicialmente, participavam das atividades nuas, mas com o tempo passaram a se cobrir, por exemplo, com maiôs de duas peças assim como foi descrito em alguns mosaicos encontrados da Antiguidade. A organização e a administração dos Jogos Heranos eram de responsabilidade das dezesseis sacerdotisas de Hera, elas dirigiam a prova esportiva e, a cada cinco anos, teciam o véu consagrado à deusa (GODOY, 1996).

Ao redor do símbolo de fertilidade aderido às mulheres, os "Jogos Heranos" desenvolviam um processo de seleção para as moças que remetiam à idéia da terra cultivada, sendo semeada e arada "três vezes" por ano para produzir. Além desse fato, como resposta às forças da natureza, esses jogos deveriam ocorrer anualmente, remetendo-se ao ciclo natural produtor.

No entanto, logo depois, em prol do ritual a Zeus que impunha a festividade de maneira quadrienal, as hereas passaram a competir a cada quatro anos, um mês antes ou após os Jogos Olímpicos. No Templo de Hera, edificado em meados de VII d.C., foram descobertas algumas inscrições com os nomes de vencedoras nos Jogos Gregos. Hera significava para a antiguidade clássica a emancipação das virtudes domésticas e a esposa-irmã de Zeus (DURANTEZ, 1975).

Por mais que muitas mulheres tenham se destacado nesse evento específico, no qual puderam demonstrar o seu potencial em diferentes atividades, não era permitida, de maneira geral, a participação feminina ativa ou como espectadora nos Jogos Olímpicos. Pausânias, geógrafo e historiador do século II, escreveu acerca de uma lei em Elida que proibia a presença de qualquer mulher nos Jogos Olímpicos.

Dizem que nenhuma mulher teria sido surpreendida confrontando essa lei, exceto Callipateira, filha e irmã de atletas coroados no estádio. Disfarçada em trajes masculinos conseguira acompa-

Movimento, Porto Alegre, v.12, n. 03, p. 99-121, setembro/dezembro de 2006. 
nhar o filho Pisidoro, como seu instrutor. Vendo Pisidoro vitorioso em uma das lutas, a mãe, no auge do entusiasmo larga as vestes masculinas para se lançar na arena ao encontro do vencedor (BOGA, 1964). Apenas, por respeito a seu pai, irmãos e ao filho, todos campeões olímpicos, ela ficou impune. Contudo foi promulgada uma lei que exigia a todos os atletas desnudarem-se antes de entrarem na arena (DURANTEZ, 1975).

Callipateira, enfim, conseguiu escapar do castigo que consistia em lançar a mulher que ousasse penetrar no estádio, do alto do rochedo Typeu (FAURIA, 1973). Segundo Pausânias, as jovens assistiam às provas eqüestres, porque podiam chegar ao hipódromo sem necessidade de atravessar o Altis, bosque sagrado de Olímpia (GODOY, 1996). Lembrando que Olímpia era localizada em terras montanhosas, de difícil acesso, sem vias de comunicação, dificultando por este motivo a jornada ao templo de Júpiter (BOGA, 1964).

Apesar das leis e regras que tentavam afastar as mulheres do campo atlético competitivo dos homens, DURANTEZ (1975) afirma que há algumas citações contraditórias acerca dessa restrição. Sempre e quando a sua presença não for proibida em Olimpia, as mulheres podiam subir ao prodisis durante qualquer ritual de sacrifício oferecido a Zeus, mas não durante o ritual solene de sacrifício quadrienal olímpico. Outra contradição foi ressaltada pela imagem da mulher campeã nas modalidades eqüestres como exemplificado, anteriormente, com a famosa Kyniska e Belistiche, ou seja, a lei de Elida não impedia que uma mulher competisse e triunfasse nas provas hípicas de Olimpia.

$\mathrm{Na}$ verdade, as mulheres não eram proibidas (no sentido total do termo) à participação nos Jogos Olímpicos. Houve exceções que foram ocasionadas, muitas vezes, pela intervenção do status político e social do pai ou de irmãos. Havia uma rede extensa de limitações e regras que impossibilitavam a expressão feminina em quase todas as atividades que foram, por mui-

Movimento, Porto Alegre, v.12, n. 03, p. 99-121, setembro/dezembro de 2006. 
to tempo, geridas somente pelos homens. As explicações para a ausência das mulheres nos jogos eram, por um lado, impedir que as mulheres grávidas passassem pelas fortes emoções do estádio, e por outro lado, havia como justificativa o fato de já existirem os "Jogos Heranos" especificamente, organizados para o sexo feminino.

Através de várias comprovações iconográficas vemos a diferenciação que existia entre a educação das moças e dos rapazes na Grécia Antiga. As jovens não participavam dos jogos do estádio (exceto em Esparta), contudo, era embargada uma grande importância à formação dessas como poetisas, músicas, dançarinas e, às vezes, como nadadoras e ginastas. Os rituais femininos de iniciação também possuíam valor na Grécia. O ritual de arktèia, em Brauron, foi um dos mais conhecidos. Nesse santuário, meninas com menos de dez anos, cuidadosamente escolhidas, eram reunidas para participarem das festas em honra da "ursa". Elas deviam "imitar a ursa", ou seja, realizarem de rituais que envolviam animais selvagens, práticas de caça, disfarces animais, etc (SCHNAPP, 1996).

A atuação da mulher na sociedade grega restringia-se às aplicações da vida doméstica, o que envolvia, fundamentalmente, a geração de filhos, futuros cidadãos. Em total submissão aos homens, elas não eram consideradas cidadãs, assim a sua expressão cívica em Atenas era estruturada em primeira vista pelo domínio patriarcal e depois do casamento pelo do marido, a essa intercalação entre tutores correspondia o estatuto da mulher. Dessa forma, as mulheres da civilização grega tinham a função de garantir a reprodução da sociedade, não somente gerando novos seres, mas de afirmar os costumes que preservavam a supremacia masculina. Elas administravam a vida familiar, promovendo o bom funcionamento das tarefas domésticas e religiosas (GONÇALVES, SILVA; CARVALHO, 1997).

Movimento, Porto Alegre, v.12, n. 03, p. 99-121, setembro/dezembro de 2006. 


\section{CONSIDERAÇÕES FINAIS}

A história subsidia um caminho à análise do contexto do Esporte contemporâneo, ressaltando a caracterização da figura da mulher. Na sociedade contemporânea, falamos sem titubeios de uma participação expressiva das mulheres em diferentes modalidades esportivas, sendo consagradas nos Jogos Olímpicos ou mesmo em outros eventos organizados para o espetáculo esportivo. Dessa forma, as discussões a serem desenvolvidas acerca da mulher no Esporte atual não podem ter o mesmo parâmetro que havia na Antigüidade, momento histórico no qual esse grupo permanecia, em grande medida, excluído da participação nesses eventos. No entanto, há uma linha que demarca essas questões de forma semelhante no transcurso da história da Antiguidade até os dias atuais.

A essa linha demarcatória vamos chamar de "cultura", um conjunto de valores, costumes e tradições que direcionam a sociedade, atribuindo-lhe uma caracterização específica, um contexto que passa a marcar a sua existência no tempo. Mas como podemos determinar a cultura como o "instrumento" que vai nos transportar em diversos momentos do contexto da Antiguidade ao mundo contemporâneo?

$\mathrm{Na}$ busca por diferentes sociedades, na qual por correspondência temos diferentes culturas multiplicadas pela diferenciação dessas no decorrer das épocas, em diferentes momentos históricos, sempre vamos encontrar uma distinção entre os gêneros, ou seja, os papéis do homem e da mulher são distintos em cada sociedade.

O que o texto em questão abordou foi justamente um recorte desse contexto. Um recorte histórico da participação das mulheres na civilização grega, particularmente, como essas mulheres quebraram várias barreiras que definiam seus corpos como inaptos ou indignos à homenagem aos deuses, como se repercutia nos Jogos Olímpicos. Nas Olimpíadas contemporâneas, as mulheres ocupam um espaço oficial - temos as categorias femininas em diver-

Movimento, Porto Alegre, v.12, n. 03, p. 99-121, setembro/dezembro de 2006. 
sas modalidades, muitas até consideradas como supremacia esportiva masculina como, por exemplo, o futebol.

Na verdade, o futebol é um exemplo viável e oportuno nesse contexto, no qual podemos ressaltar diferentes questões, isso porque, pelo caráter histórico-cultural que ocupa no Brasil como uma prática masculina e sem incentivos para a prática feminina, tudo o mais que vemos acerca da participação das mulheres no futebol acaba surtindo uma imagem de "moda" ou um efeito de menosprezo frente às possibilidades dos homens nessa prática.

Essa questão ocupa um espaço fundamental em nossa educação, assim como DAOLIO (1995) ressalta, a aptidão física também é uma prerrogativa cultural. Para essa discussão o autor utiliza-se do fato de os meninos brasileiros, como se diz correntemente, "nascerem sabendo jogar futebol", quando de forma contrária, ainda segundo o senso comum, podemos dizer que as meninas brasileiras, além de não nascerem sabendo, nunca conseguem aprender a jogar futebol. Contudo, devemos lembrar que o primeiro brinquedo que o menino ganha é uma bola, como se não bastasse, há todo um reforço social incentivando-o aos primeiros chutes, ao contrário da menina, que, afora não ser estimulada, é proibida de brincar com bola utilizando os pés.

A cultura apresenta um papel norteador a partir do momento que identificamos diferentes valores em nossa sociedade também determinando as participações esportivas entre os gêneros. Uma modalidade que podemos adotar como exemplo é o nado sincronizado, no qual não há representantes masculinos. Uma inferência a esse aspecto é a permanência de qualidades a qual simbolizam o mundo masculino e o mundo feminino. A mulher representa a graciosidade e a leveza, ao passo que os homens, a força e a resistência. Esses valores são determinantes de maneira geral nas sociedades, mas também ocupam um lugar particularizado nas práticas esportivas.

O nado sincronizado e o levantamento de peso são extremi-

Movimento, Porto Alegre, v.12, n. 03, p. 99-121, setembro/dezembro de 2006. 
dades dessa discussão, por um lado a restrição dos homens à modalidade devido a graciosidade inerente nos movimentos e por outro lado a força exigida no levantamento de peso. Muitos dos fatores associados a essas determinações de prática de acordo com o gênero são apenas de caráter biológico, ou seja, o tipo de modalidade no qual homens e mulheres se envolvem e alcançam um status particular está somente relacionado com pré-requisitos físicos, ou, devemos lembrar que muitas dessas diferenciações não passam nem por esses pré-requisitos. Os homens não praticam o nado sincronizado não porque sua estrutura corporal impeça a realização dessa atividade, o que ocorre é justamente o que a sociedade espera desse diferentes gêneros, quais as capacidades e funções que cada um deve desempenhar no meio social.

$\mathrm{Na}$ Grécia Antiga havia um círculo de justificativas para a não participação nos Jogos Olímpicos, desde os perigos à saúde da mulher com emoções ocasionadas no Estádio, etc. Portanto, se assumirmos essas justificativas como veículo de uma diferenciação dos gêneros na prática esportiva, diríamos que para a sociedade contemporânea apenas foram modificadas as justificativas, mas os objetivos continuam semelhantes: o primórdio histórico de uma supremacia masculina, principalmente, em atividades públicas como as realizadas no Estádio, nos Jogos Olímpicos.

Devemos também refletir acerca da questão de que em momentos de glória das mulheres no Esporte, quando essas alçam performances espantosas ouvimos comentários que sempre levam a comparações com as marcas atingidas pelos homens, ou mesmo, como essas "fugiram da imagem do corpo frágil a elas correlacionado historicamente". Estamos enaltecendo a vitória e superação dessas mulheres ou estamos, muitas vezes, tentando colocá-las em uma tabela como simplesmente um "desvio padrão". Se partirmos da segunda hipótese, a idéia da participação feminina no Esporte acaba restringindo-se a uma via paralela, com um nível abaixo à performance esportiva dos homens.

Movimento, Porto Alegre, v.12, n. 03, p. 99-121, setembro/dezembro de 2006. 
A importância dos estudos históricos e antropológicos com vista às mulheres no Esporte traz a vigência dessas reflexões, enfatizando a eqüidade como princípio a ser enfatizado em todas as intervenções do profissional de Educação Física, buscando aplicar o respeito às diferenças como características inerentes ao convívio entre os gêneros. As diferenças biológicas são nítidas, mas devem ser compreendidas simplesmente como diferenças e não dentro de "níveis de limitações". As diferenças existem e o profissional de Educação Física deve assumi-las como um alerta à necessidade de adaptações em suas aulas, para que possa trazer uma prática não-excludente e participativa a todos, tanto no que diz respeito às distinções referentes ao gênero e a atividade física, como também, outras diferenças que apareçam motivadas por modelos de corpo construídos socialmente.

"Guess Who Comes to Stadium: it is Atalante!"-
The History of Women in the Greek Games
Abstracts: This paper discusses the participation
of women in Greek Games, especially the Olympic
Games. By analyzing the participation of women in
these events, the paper exposes the arguments
which determined the limitation, and even the
prohibition imposed on this group on taking part of
masculine activities in Greek civilization. As to
contextualize these arguments, this research also
accounts for the main characteristics of each stage
of Greek education - the Spartan one, in which
women were given more opportunity to practice
sports, and the Athenian one, when female
education was restricted to family and
housekeeping, with no attention paid to the athletic
condition of these mothers as to fulfill their duties at
home or even give birth to healthy descendants.
Keywords: History. Greek games. Women.

Movimento, Porto Alegre, v.12, n. 03, p. 99-121, setembro/dezembro de 2006. 
Aquí es aparece en el estadio: es atalante! “- la
historia de las mujeres en el juegos griegos
Resumen: El estudio buscó indicaciones de la
participación femenina en los juegos griegos, en-
tre ellos, los Juegos Olímpicos. Analizando la
participación de las mujeres en estos
acontecimientos, el texto aborda las justificaciones
que determinaron la prohibición, o iguales, la
limitación de este grupo en ser parte de actividades
del mundo masculino en la civilización griega. A
contextualizar estas justificaciones, el estudio
también destaca las características principales de
cada fase educativa, distinguiendo la educación
llevado a través en Esparta, en el cual las mujeres
possuiam un espacio más grande para la práctica
de ejercicios y en Atenas, en que la educación
femenina lo restringió el carácter doméstico, no
teniendo la preocupación con la preparación física
de las madres para jugar sus tareas del hogar, o
igual, de generar a niños robustos y sanos.
Palabras Clave: Historia. Juegos griegos.
Mujeres.

\section{REFERÊNCIAS}

ARANHA, M. L. de A. História da educação. São Paulo: Moderna, 1989.

BOGA, M. Jogos olimpicos na antiga Grécia e olimpismo moderno. Lisboa: Lucas, [1964].

DAOLIO, J. Da cultura do corpo. Campinas: Papirus, 1995.

DURANTEZ, C. Olímpia y los juegos olímpicos antiguos. Burlada-Pamplona: San Blas, 1975. 2 v.

FAURIA, J. Heroes olimpicos. Madrid: Instituto Nacional de Educación Física, 1973.

GODOY, L. Os jogos olímpicos na Grécia antiga. São Paulo: Nova Alexandria, 1996.

GONÇALVES, A. T. M; SILVA, G. V.; CARVALHO, M. M. Sobre as representações femininas na Antigüidade. Estudos de História, Franca, v.4; n.2; p.7-18, 1997.

GRIFI, G. História da educação física e do esporte. Porto Alegre: D.C. Luzzatto, 1989.

Movimento, Porto Alegre, v.12, n. 03, p. 99-121, setembro/dezembro de 2006. 
KYLE, D. G. "The only woman in all Greece": Kyniska, Agesilaus, Alcibiades and Olympia. Journal of Sport History, v.30, n.2, p. 183-203, 2003.

MONROE, P. História da educação. São Paulo: Editora Nacional, 1972

RAMOS, J. J. Os Exercícios físicos na história e na arte: do homem primitivo aos nossos dias. São Paulo: IBRASA, 1982.

SANTOS, T. M. Noções de história da educação. São Paulo: Editora Nacional, 1958.

SCHNAPP, A. A imagem dos jovens na cidade grega. In: LEVI, G.; SCHMITT, J. (Org.). História dos jovens: da antiguidade à era moderna. São Paulo: Companhia das Letras, 1996. 